\title{
RESEARCH
}

\section{Landscapes of Heathrow: The Aircraft Landing Gear Compartment and the Politics of Global Transfer}

\author{
Nicholas Ferguson and Andreas Hahn
}

This paper, an output of an art research project, explores the agency of the aircraft landing gear compartment in global transfer. Through the prism of historical events involving aircraft preparing to land at London Heathrow, it reflects on the part played by the compartment in ecological and humanitarian struggle. Its theoretical frameworks include John Ruskin's writing on geology, new materialism, and the planetary garden. These are brought into proximity with methodologies and collaborations developed through practice-based elements of the research, such as architectural modelling, geoforensic science and exhibition making. It incorporates an account of the process of reconstructing a compartment, as well as extracts from a microstratigraphic survey commissioned as part of the project. It examines the landing gear compartment's capacity as a vessel in which dust, seeds, insects, pollen and even people are transported around the globe. It explores, too, its role as expository instrument, as far as it makes available for inspection the politics inscribed into its formal, spatial and temporal configuration. The paper argues that the wheel bay gives shape to a set of otherwise intangible aeromobilities, knowledge of which is integral to a nuanced understanding of the political geography of London Heathrow.

Keywords: art and mobilities; aircraft wheel bay; Heathrow; planetary garden; migrant; political geography of air; spatial inequality

In 1981 the aphid specialist H.L.G. Stroyan speculated that Californian aphids found at the Royal Botanical Gardens, Kew, had arrived from the United States on a transatlantic aircraft (1981). Stroyan did not specify how he thought the aphids reached the gardens. But Kew lies some five kilometres east of London Heathrow
(Figure 1) and is routinely overflown. Could it be that the aphids, Macrosiphum albifrons (Figure 2), had stowed away in the wheel bay, the cavity into which the aircraft's landing gear retract during flight, and tumbled out into the temperate air above the gardens when the wheels were extended in preparation for arrival?

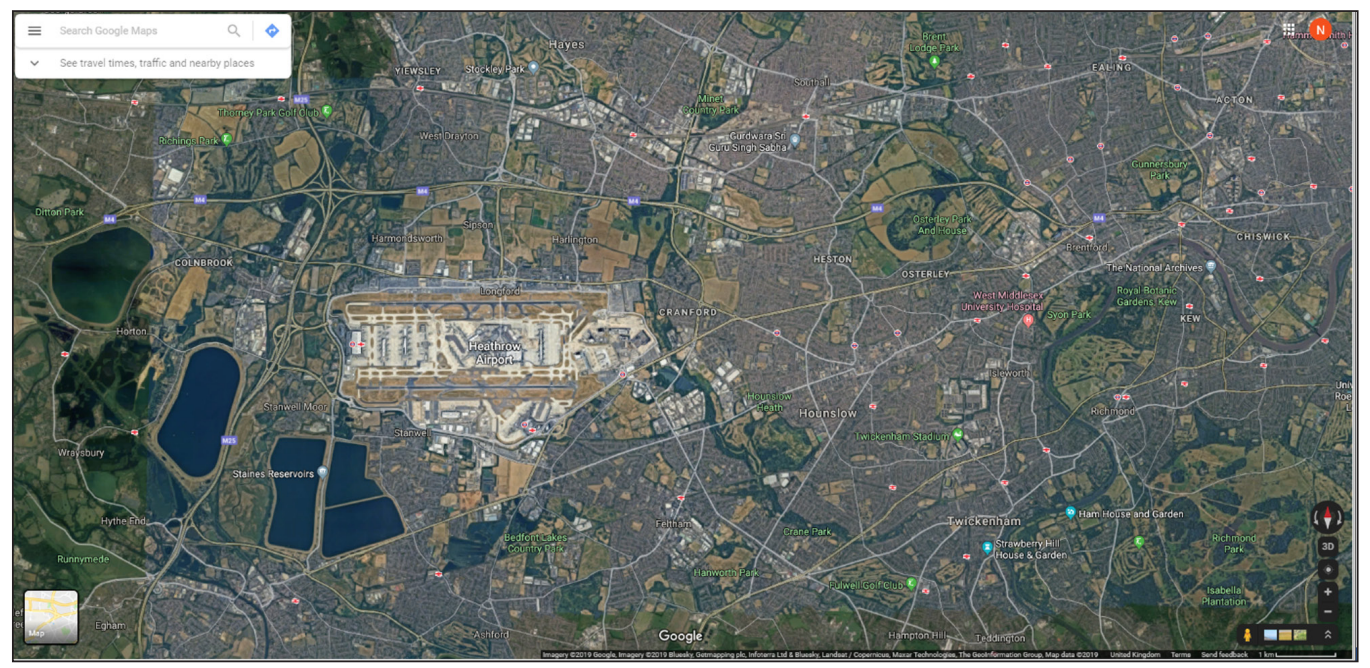

Figure 1: Satellite image showing Heathrow (centre left) and Kew Gardens (centre right). Image: Google Earth. 


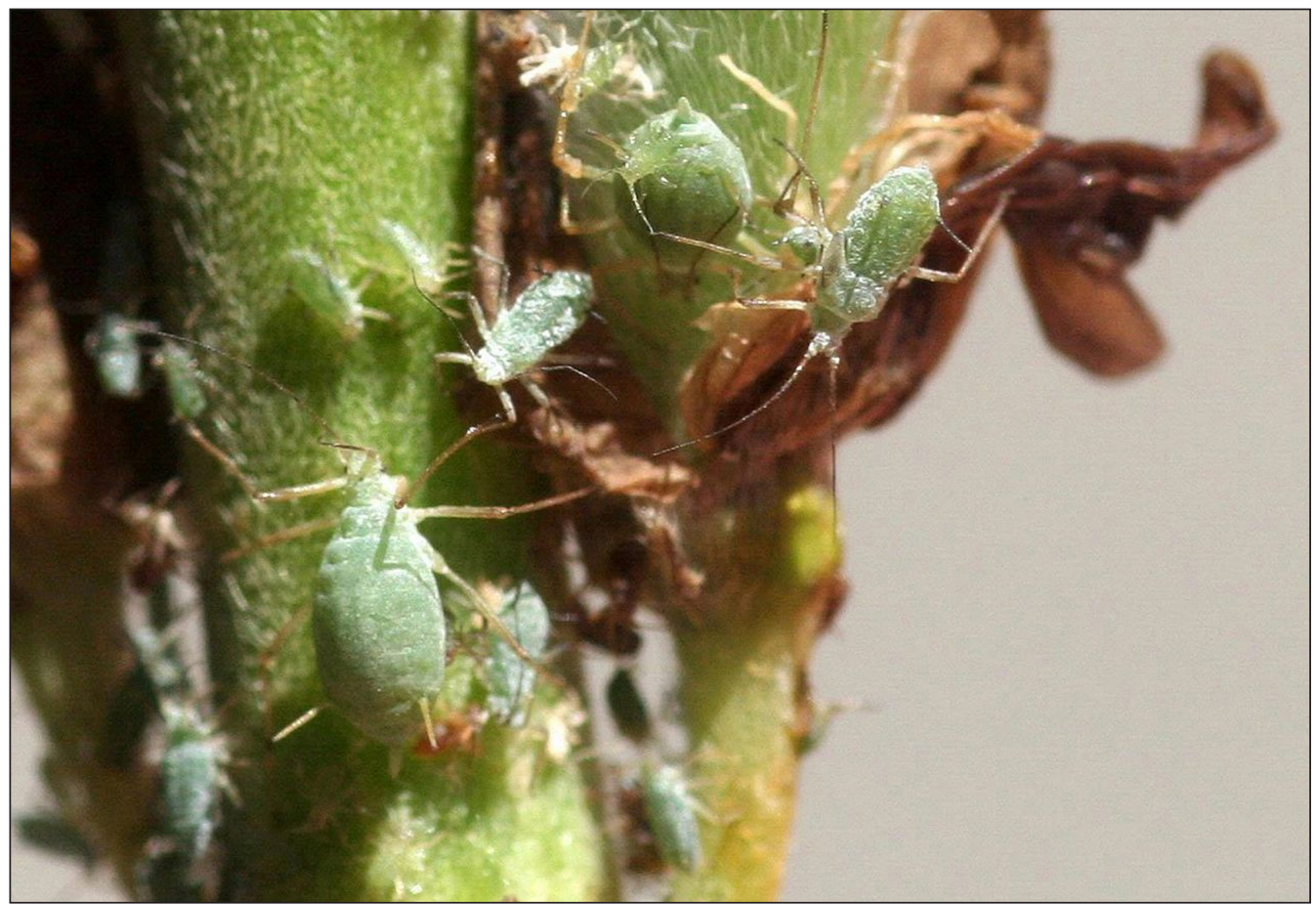

Figure 2: Californian aphids (Macrosiphum albifrons). Photograph: Whitney Cranshaw. Source: Creative Commons.

Whether or not they arrived this way, the hypothesis draws attention to the potential of the wheel bay as a vehicle for global transfer. It also highlights its capacity as a repository of material gathered from corners of the globe. For if not aphids, then surely other travellers? Inscribed in the entomologist's report would seem to be accounts of planetary stirring and an unmapped port. And to the mind prey to the allegorical impulse, an incident involving clandestine aphids in an aircraft wheel bay is not easily taken at face value. At large is a truth about the global transfer of the systemically illegitimate, unrepresented, and possibly un-representable. It is hard to believe that, had they come to settle somewhere other than in the royal gardens at Kew, the aphids would have been discovered, let alone caught the attention of those empowered to classify them. These were precarious bodies caught up in machinery that had distributed them well beyond the horizons of natural planetary stirring, as facilitated by the wind, ocean currents and altitudinal airstreams. And one displaced body detected through happenstance signals the invisible presence of others.

Discoveries in these areas could have implications for an accurate mapping of the airport boundary. Insofar as the anthropogenic transfer of organisms and matter shapes the natural world, they would also have implications for the history of landscaping. Where the displacement of matter, living or otherwise, poses a risk to ecology, they could shape the evaluation of aviation in these terms. Where transportation crosses international borders, they might even help write histories of political struggle.

\section{II}

In the Summer of 2019, the British press reported on a passenger who had fallen from an aircraft. A presumed migrant, he plummeted to his death on July 2 from the wheel bay of Kenya Airways flight KQ 100 from Nairobi,
Kenya, to London Heathrow as the plane was made ready to land (Busby 2019). While the authorities searched for a name for the key protagonist, the human element of the story was substituted by the figure of one John Baldock, an Oxford graduate, who had been sunbathing in his back garden in Clapham, South West London. In a display of values that may have astonished some readers, the media regaled the public with how Baldock had been inconvenienced by the descent of the reckless man, not least by the damage caused to two patio slabs and the AstroTurf lawn at his $£ 2.3$ million residence (Duell, Fielding and Dyer 2019).

The Clapham stowaway brought displacement by way of the aircraft wheel bay into the public eye. Like an unresolved disagreement that returns with enhanced vigour, the issue came to affect people directly. Yet events at Clapham failed to propel a new politics. Even as the migrant stands to be counted through his appearance in the garden, he disappears in the narrative. It is as if bare life has not so much moved across the surface of the planet, as travelled from one planet to another. At the point of departure, it is accounted and visible. On arrival in London, it is neither. ${ }^{1}$ At large in the story's telling would seem to be a version of the world that is unwilling or unable to accommodate the spatial and political reality of what happened. The histories that have shaped this consciousness are beyond the scope of this account. But with respect to its manifestation in the British press, we may speculate with some confidence that it is born of liberal subjectivity, economic and soft power interests, and of the history of London's interactions with the world.

What violence, what rupture of capital accumulation, what disruption of public life would it take to change things? And what politics and practice might help connect the spatial, ethical, and epistemic challenges presented by the narrative so far? 
We may begin by noting that at the centre of the issue sits the aircraft wheel bay. The incident is played out through its material configuration and its spatial trajectories. It follows that, in the same way that a groom might examine the latch and hinge of the gate from which the proverbial horse has bolted, researchers into the Heathrow landscape should take a good look at the spatial and temporal conditions of the wheel bay of the longhaul aircraft. Inspect its design, surfaces, and mechanism. Draw its vectors and points across the globe. Extrapolate, and think these thingly qualities in relation to the philosophical problems to which they point: internalities and externalities, planetary and political globes, the seen and unseen, the permitted and forbidden.

This co-authored paper forms part of a project that has taken up precisely such a proposition. Initiated in 2017, the project deploys fieldwork, creative pedagogies, sculpture, and interdisciplinary research. It draws on qualitative data of narrative and hearsay, on architectural modelling techniques, and on data collection of forensic science commissioned as part of the project. The forensic investigations were conducted by Dr Andreas Hahn and his write up forms Section VII of this paper. Other critical and historical frameworks are art, forensic architecture, postcolonial theory, and spatial and materialist theory. The arts have a strong tradition of attending to outliers - liminal spaces, things out of place, the wretched of the earth, violence on the threshold of detectability (Fanon 2001; Landy 2002; Farley and Simmonds Roberts 2011; Weizman 2017). The project contributes to the tradition by probing the cargo of the long-haul aircraft landing gear compartment.

\section{III}

There are on Google Images surprisingly few photographs of wheel-bays of the most widely used long-haul aircraft, the Boeing 777. There are numerous images of landing gear photographed by aircraft enthusiasts as the planes zoom over, but the cavities into which they retract upon take off are invariably grainy, gloomy, and formally inconclusive (Figure 3).

The process of searching for wheel bay images is complicated by the fact that in the English language at least, the wheel bay has no decisive name. The media often call it the landing gear compartment. In blogs posted by the enthusiasts it is sometimes called the wheel well, at others the wheel bay. The name 'well' is suggestive of a vessel and points to a sedimentary capacity, as well as to the possibility of things being lost or discarded within it. But the terminology is also adorned by historic usage of the well and conjures folkloric hope that benevolent deities might be housed inside. Wheel bay is the more widely used of the two terms and indicative of an allocated space, in this case the aircraft wheels. It would imply too that contents other than the aircraft wheels do not belong or, to borrow from a definition of dirt by anthropologist Mary Douglas, they are 'matter out of place' (2002: 44).

There are, to my knowledge, no technical drawings of the Boeing 777 wheel bay. After offering to help with my search, a fluid mechanics engineer at the National Physics Laboratory, Teddington, drew a blank on the diagram databases which she uses for aeronautics projects. A patent attorney with experience of locating rival patent claims ran into a similar difficulty. He found drawings of wing flaps, landing gear, hydraulics, brakes, tyres, but not the wheel bay itself. The problem, he explained in the pub one evening, lies in the fact that the wheel bay is a cavity. A patent would have claimed the retractable wheel, not the space, unless its function went over and beyond simply housing the wheels. Sociologist Bruno Latour famously asked how 'matters of concern' (2006) might be constructed in the absence of the Thingly. The agency of the wheel bay suggests that Latour's materialist philosophy should be extended to include non-things. His question might be reformulated: 'How might matters of concern be constructed in the absence of the non-Thingly?'

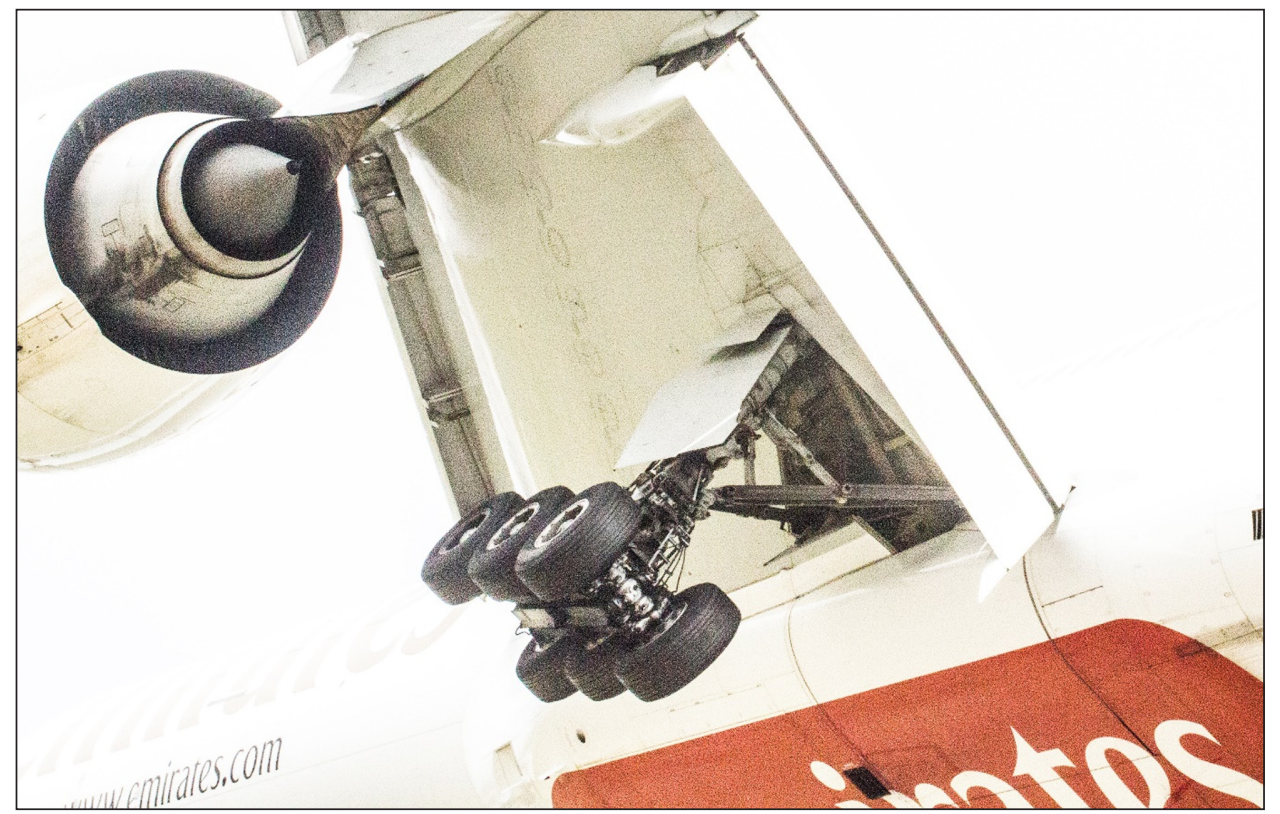

Figure 3: Boeing 777 showing partially open wheel bay. Photograph: Nick Ferguson. 
As it happens, the wheel bay would seem to promise a valuable capability precisely by virtue of its 'non-thing' status. For, as the micro historian Carlo Ginzburg has shown us, if you want to establish truth, you need to look in the places that people have not thought to construct or conceal it (Ginzburg and Davin 1980). An unauthored gap between extraordinary feats of engineering, the wheel bay is not conceived of for semantic scrutiny and no message is consciously planted there. It is the counterpoint to the tailfin, which is emblazoned with national or corporate livery. It is a gap, a space off its guard, the engineering equivalent to a human ear or toe in a forged art masterpiece.

\section{IV}

A primary objective of the inquiry in its initial stages was to set in motion a process of de-abstraction. The idea was to give agency, empirical mass, realism even, to the hitherto vagaries of the unseen and un-experienced. I would need to gain local, real-time experience of the wheel bay cavity and establish, first-hand, a sense of the space in which matter is transported: size, shape, distance from the ground. Related to this was an expectation that the experience - "being there' (Wagner 2005) - might act as a catalyst for thought. For there is always a relationship between thought and the environment in which ideas are born.

On March 15, 2019, my ambitions took me to an aircraft boneyard in the Cotswolds, England where, joined by fellow artist Richard Beard, I inspected and measured up the wheel-bay of Ethiad Airways Boeing 777-200LR A6-LRC (Figures 4 and 5). I gained access via a ladder provided by an engineer charged with our escort and, over a stiff easterly wind, relayed measurements to Richard on the ground. The space in which I found myself

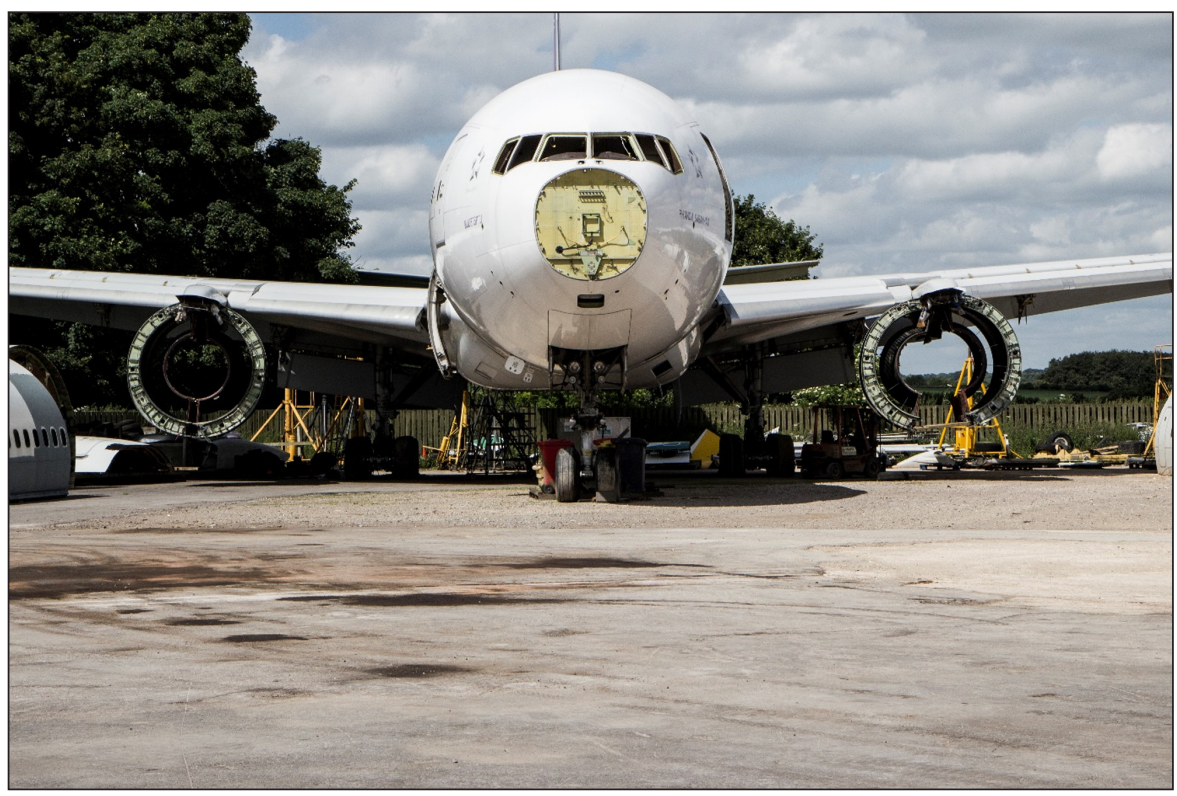

Figure 4: Decommissioned Boeing 777, Cotswold Airport. Photograph: Nick Ferguson.

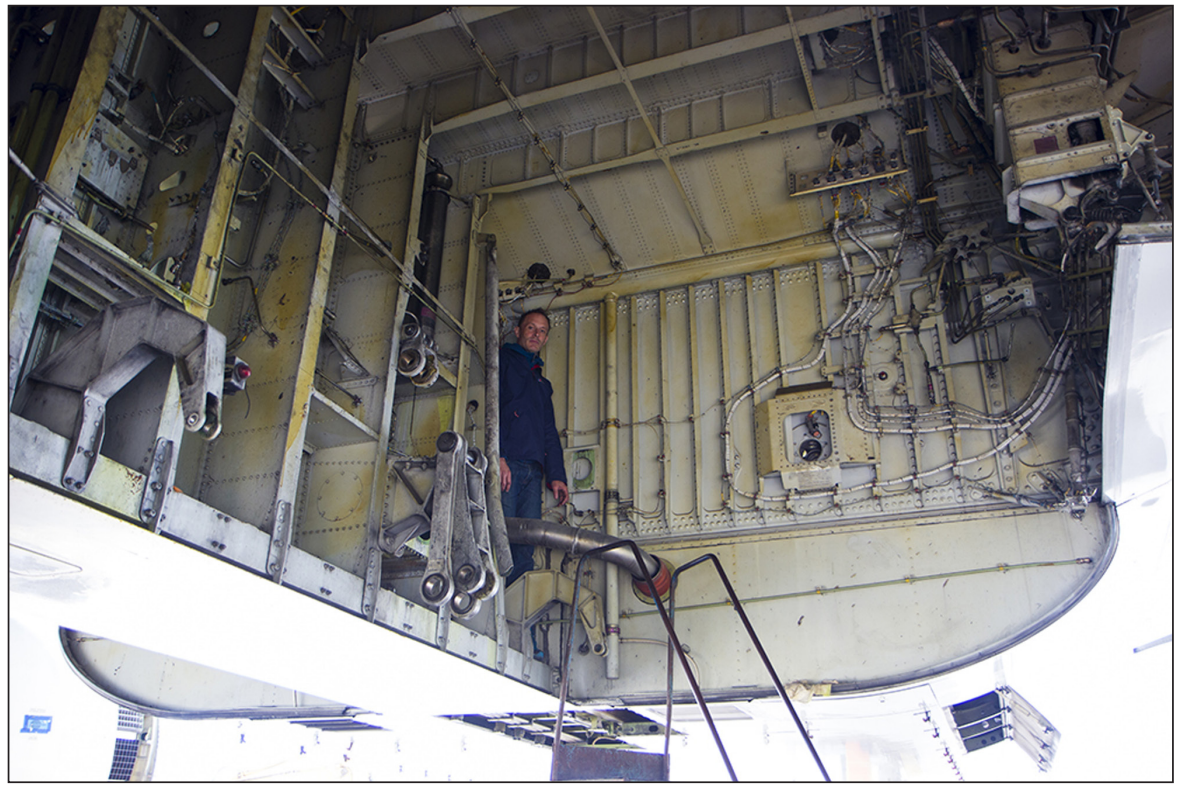

Figure 5: Inspecting the Boeing 777 landing gear compartment. Photograph: Richard Beard. 
is cavernous. Viewed in cross section, it is shaped like a letter $\mathrm{P}$, only turned clockwise through 90 degrees. The head of the letter sits within the fuselage of the plane while the tail forms the beginning of the wing. The largest section (the head of the letter P) is a room of about $60 \mathrm{~m}^{3}$, possibly larger, and running the length of its innermost wall (the wall furthest from the wing tip), is a ledge 38.5 $\mathrm{cm}$ deep, $2.8 \mathrm{~m}$ high. This is compartmentalised into 8 roughly equal spaces by a series of vertical struts that run to the ceiling. The smaller section (the tail of the letter P) lies within the wing and is highly irregular in shape, its top and bottom curving to fulfil the aerodynamic requirements of the upper and lower surfaces of the wing.

While I was perched on the ledge, my mind turned to the figure of the stowaway. Since first hearing of migrants arriving in London by air, I had established the following. That it is not publicly known how many have fallen over London. A freedom of information request to the CAA in 2015 confirmed 6 to the UK between 2004 and 2014 (CAA, 2015). A Wikipedia page dedicated to the topic lists two further incidents in London, one in 2015 and one in 2019. Globally, there is even less certainty of the numbers involved. The same webpage relays that 113 cases have been reported in the US since 1947 and appeals to the reader to expand a list under construction (Wikipedia). It is also clear from the geography in the reports that incidents are scattered across continents and islands, and airports are often in isolated parts of the countryside or on the coast. When people drop, they can do so without trace, so the numbers are likely to be considerably higher.

Also noteworthy is the fact that it is to the international public such as the one which has assembled Wikipedia, not national governments that we are obliged to turn in pursuit of a reckoning. Nation states do not even count the daily $\mathrm{Co}_{2}$ emissions from planes towards their output: how much less are they moved to take responsibility for a migrant deposited into their airspace. Their indifference to these matters is highly contradictory, a case of wanting to have its cake and eat it projected onto a global screen. In the case of Britain, Heathrow is one of the nation's core infrastructures. This is evident from the fact that expansion plans were readily adopted into policy (UK Government 2018), as well as from the ongoing use of air transport for the regulation of populations through, for instance, deportation (Taylor 2018). Thus, national interests and neo-colonial agendas are served by the airport, yet when it comes to accountability, the duty of care is tacitly regarded as supra-national. To the British government that has not yet so much as acknowledged their presence, stowaways are not even a number, let alone a name. They disappear between states, just as they vanish between the lines of a newspaper report.

Sociologist Les Back has problematised this embedded prejudice by drawing an analogy with the mythical figure of Icarus, as depicted by Pieter Breugel in the sixteenth century (2003). Despite featuring in its title, Icarus is barely noticeable in Breugel's painting Landscape with the Fall of Icarus (1558). The viewer is presented with a view in which people are going about their daily activities: ploughing the land, fishing, navigating the straits. A shepherd is looking into the sky but if he is looking for Icarus, he has missed him. For Icarus has already plunged into the sea. We must look hard to glimpse what is left of him - no more than his right leg - before it disappears below the surface. Back characterises the attention of the bystanders as active inaction and links it to an understanding of the world shaped by unchecked economic endeavour. He formulates the contemporary relevance of the analogy so: 'Today's Icarus is carried skywards by steel wings that are not melted by the sun. Rather, the fall from the sky is produced under the white heat of globalization' (Back 2003: 350).

From my ledge it was possible to satisfy technical aspects of questions of Icarus's plight. There is room enough for a fugitive, but the spot in which to hide would have to be chosen carefully if you were to avoid being crushed by the landing gear. You'd need to get on the shelf where hydraulic fluids are stored, or into a triangular alcove that extends forwards along the flank of the aircraft for about a metre, but you would not discover this until the landing gear was retracting, by which time it would be too late to move. The chances of a terrified, adrenalin-fuelled refugee working all this out in the hours of darkness are slim indeed. I also laid to rest a myth that reportedly circulates among would-be refugees. There is no secret door to the cabin.

My thoughts returned too, to the aphids at Kew. As the plane had stood on the Californian tarmac, or as it gathered speed for take-off, the insects would have found themselves drawn up by displaced air and driven or sucked inside where, as the undercarriage retracted and the doors closed, they were temporarily housed. Accompanying the aphids would have been the air on which they rode, as well as a host of other airborne matter: fellow insects, seeds, moisture, dust, particulates, pollen and aeroplankton. Each of these taxonomies contains further subclassifications. Aeroplankton for instance includes mosses, microbes such as viruses, fungi bacteria, protists, liverworts. Fungi alone amount to more than two million types, (Hawksworth and Lücking 2017) liverworts 9,000 (Haughian et al. 2016). In sum, the wheel bay functions as a capsule in which a host of organic and inorganic matter of unimaginable variety is routinely collected, sealed in upon retraction of the landing gear, and transported to a distant location.

On the destination approach the process is reversed. A jet is travelling at around 180 nautical miles per hour (knots) when the landing gear is opened. By way of comparison, a gust of wind is classified as hurricane force at 64 knots, meaning that the resistance of the air against the body of the advancing plane is equivalent to that of a triple hurricane force wind. As the landing gear collides with the air, its intricate surfaces are blasted by molecules of moisture and air. Displaced, some of this this will find itself swirling into the cavity, sweeping up loose matter, and lifting it free of the aircraft. In this way, the matter is relocated from one continent to the next, so that with time, it is irrevocably reordered.

Art history is steeped in investigations into the process of planetary stirring, albeit with diverse frames of reference. They disclose something of its scope and the contexts in which it may be grounded. In her curatorial projects 
Seeds of Change artist Maria Thereza Alves has explored the dumping of ballast by ships used for the purposes of colonial expansion. The projects, performed in multiple cities, seek to identify plants inadvertently brought to Europe and North America during the period of colonial expansion and these are then used to unearth and narrate world history (Thereza Alves 2009). The air is to the twenty-first century what the sea was to the seventeenth, opening up new connections between people. And, like the ballast of the ships that travelled back and forth between continents, the contents of an aircraft wheel bay is spilled across territories, telling stories replete with political history. We have noted that $\mathrm{CO}_{2}$ emissions from aircraft are not counted towards the output of any nation state. To this omission may be added matter released into the air from the aircraft wheel bay.

Fifty or so years before Alves, the American land artist Robert Smithson used the frame of natural science rather than history to approach a related idea. In his analysis of urban decline in his hometown Passaic, New York, he wrote:

Picture in your mind's eye the sand box divided in half with black sand on one side and white sand on the other. We take a child and have him run hundreds of times clockwise in the box until the sand gets mixed and begins to turn grey; after that we have him run anti-clockwise, but the result will not be a restoration of the original division but a greater degree of greyness and an increase of entropy (Smithson 1996: 74).

Cultural theory has come full circle on Smithson, so that climate change discourses in sociology and anthropology are reinvigorating a once-eccentric artistic interest in natural science. If, as the metaphor implies, the earth is analogous to a vast sandbox, then the aviation industry is the child whose reorganisation of sand is the measure of disorder.

From the viewpoint of the aviation industry the aphid incident will have amounted to an accident. Though the insects arrived in the UK by means of human-built technology, there was no intention on the part of the carrier to transport them. The wheel bay is not designed as a cabin or even a hold, and so that which finds itself inside, whether by accident or design, is not thought in relation to quantification if it is 'thought' of at all. In economic terms, unless they travel in the cabin, transported insects are counted by airlines as an externality - a cost or benefit incurred by a third party, in this case Kew and/or the aphids.

For the executive at Kew there will have been a conflict of interest. Kew is a research and education institution whose governance and routine administration is dependent on the airport. Its corporate sponsors have included British Airways who have flown botanists and plant specimens around the world for free (HACAN 2005). Indeed, it is not impossible that the intrepid aphids arrived on the same aircraft as plants designated as cargo. There is a thin line between commitment to botanical research and corporate environmental responsibility. As if by way of demarcation, the quarantine unit has termed stowaway species 'hitchhiking pests', testifying that, while an object of study, they fall outside the version of nature which Kew's horticultural activities strive to maintain. In keeping with such principles, the Californian aphid has been classified as an invasive species (Centre for Invasive Species and Ecosystem Health, n.d). ${ }^{2}$ Thus, the unintended transfer or propagation of aphids has been systemically excluded by these industries from what counts as their professional activities.

Yet the incident jars. The dynamism of the aphids' arrival is at odds with the conservatism of the methods deployed in their investigation. For, while valuable in the classification of a species, the microscope is ill-suited to capturing the forces and vectors that distinguish their travel. Indeed, the image of the miniscule aeronauts parachuting into Crown property draws attention to other anachronisms: a walled garden as a means of enclosure in the age of air travel; Stroyan's mode of making public his findings. At little more than 300 words in a subscription journal, the latter resembles a note for a secret society more than a publicinterest issue, its brevity commensurate with reports commissioned for fellow specialists. Underlying this succinctness will have been a complex run of interrelated factors that include convention, economic constraints, and scientific rigour. The last of these is worth dwelling on, because in methodological terms it points to what is fundamentally wrong with Stroyan's report. Central to scientific rigour is the notion of objectivity. That is to say, Stroyan worked in the knowledge that, the longer the write up, the greater the risk of the personality of the observer appearing in the findings. The etymology of the term objective clarifies this point. From the Latin $o b-$ from and iactum - thrown, an object was to those who first deployed the term a thing presented to consciousness by being thrown in front of the eyes, as for example, happens when placed under a lens. Objective is the adjectival form. A true object, etymology confirms, is radically and inherently separated from its context. (Daston \& Galison 2010). Thus, the epistemic virtue of objectivity will have been secured at the cost of a more public, holistic, and interdisciplinary approach to knowledge.

Accordingly, Stroyan's report does not extend to an overview of identification methods, leaving the reader to speculate that the Petri dish and microscope presumably used to classify the intruders fulfilled the methodological conditions of his practice by isolating them from the environment. This optical and physical distancing has provided science with much of the epistemological bedrock on which its intellectual counterpart, the compartmentalisation of knowledge, is constructed. If the discovery of the Californian aphid at Kew unsettled the author beyond the requirement to identify the species and fleetingly speculate on its means of arrival, this did not register in its telling. The exercise of rescaling scientific enquiry to encompass a wider, if more abstract, object or embrace contingencies and interdependencies beyond the intellectual orbit of plant pathology was outside the scope of the endeavour. Had acumen, habits 
of thought, and networks of practice been otherwise, the material manifestation of the aphids might have relayed into political action.

\section{V}

The wheel bay walls of 777-200LR A6-LRC were caked with a yellow sludge comprising grease and dust in a layer about half a millimetre thick, considerably more in some places (Figure 6). According to the engineer, a film of grease is applied to the wheel bay at the manufacturing stage as a precaution against corrosion. The dust and further deposits of grease adhere to this like insects to flypaper, forming over the aircraft's 10-15 year lifespan a residue of all the matter picked up at airports that has not been blown away by the force of the air. In this way, matter assumes the role of witness to the otherwise unseen and unquantified material transported in the compartment. It accumulates over the course of the aircraft's history so that, with time, the wheel bay is rendered a uniquely articulated environment as if it is itself the blended sandbox, a microcosm of the planetary one which its movements have helped to create. If the analogy is pursued to its logical conclusion, it becomes clear that the earth has no stable coordinates but is an incessantly shifting and regrouping body of matter.

In his essay The Lamp of Memory the nineteenth century artist and social reformer John Ruskin contends that soot and grime on buildings constitutes a time stain that is integral to its proper understanding. Speaking of the walls of buildings he writes:

It is in their lasting witness against men, in their quiet contrast with the transitional character of all things, in the strength which, through the lapse of seasons and times, and the decline and birth of dynasties, and the changing of the face of the earth, and of the limits of the sea, maintains its sculptured shapeliness for a time insuperable, connects forgotten and following ages with each other, and half constitutes the identity, as it concentrates the sympathy, of nations; it is in that golden stain of time, that we are to look for the real light, and colour, and preciousness of architecture (Ruskin 1900: 177).

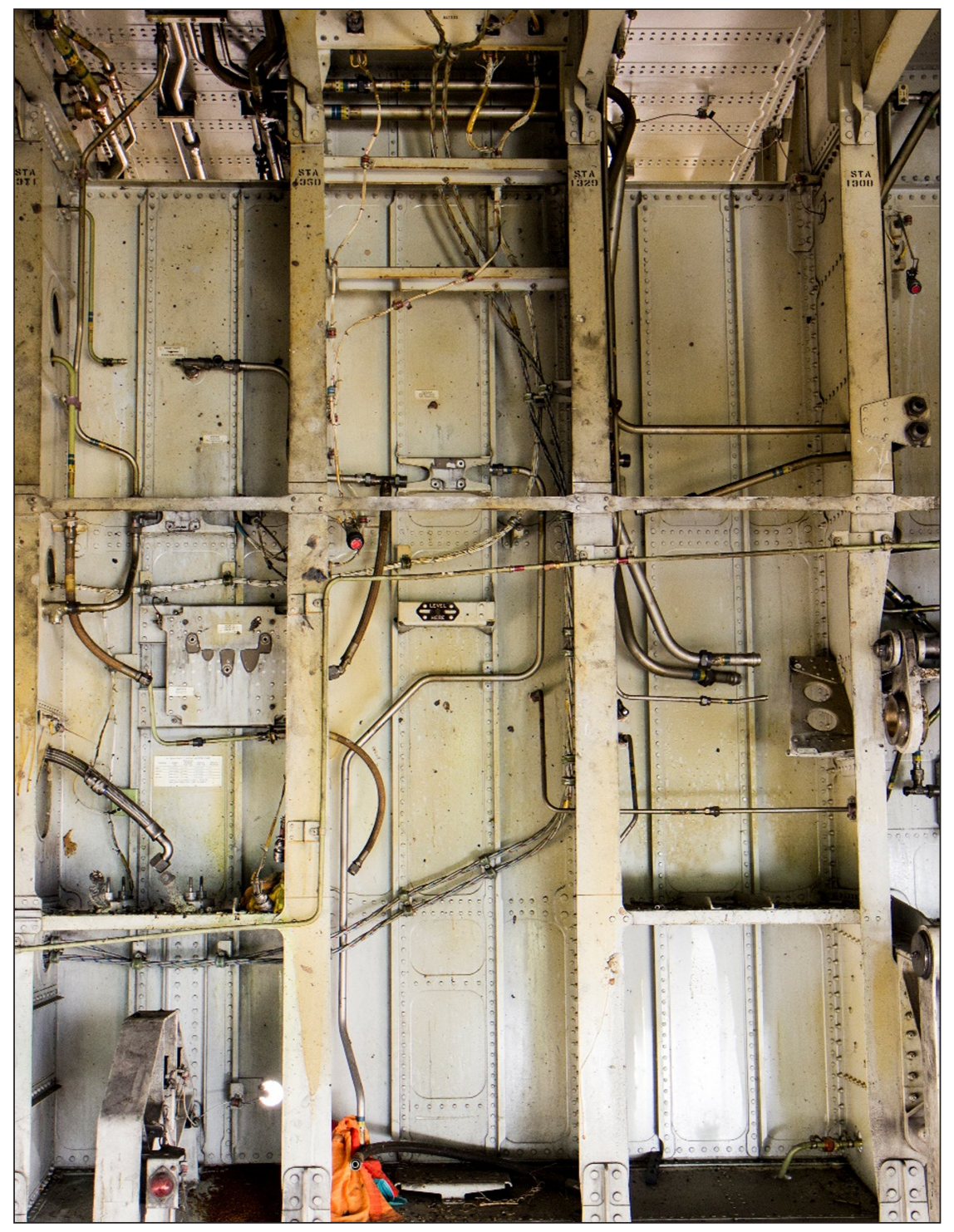

Figure 6: Boeing 777 landing gear compartment detail showing sludge on the surface. Photograph: Nick Ferguson. 
Time, he suggests, is made material (Morton 2017) and this materiality gives us access to a set of spatial and temporal relations that are otherwise lost. A similar idea is developed in the Ethics of The Dust (Ruskin, 1865) where, through a set of lessons on minerals, he probes the relationship between humans and the environment. The lessons form a dialogue in which, Alice-like, the student is radically reduced in scale and transported through a wondrous landscape of crystals, precious stones and particles ordinarily overlooked. Ruskin's geological imagination is synecdochal simultaneously conceiving of the part and the whole, so that in a back-and-forth motion, the world on one scale is used to constitute and comprehend the other. Thus, the microscopic crystal landscape has immeasurable cultural value, disclosing the interplay of time, space, matter, and humans. Comparisons between mineral relations on the microscopic scale - co-dependencies, rivalries, collaborations - stand in for others observable at the scale of the human, and vice versa. As described by Ruskin, the landscape is routinely ruined by human activities: crystals get mixed with clay, soot, and minerals in whose company they do not naturally occur, or destroyed by cleaning when crystals dissolve in water. Through these visionings, he constructs a history of the earth and a spectrum of relations useful in the present context: intra-human, human and architectural, human and earth, physical and metaphysical.

Ruskin's muddied crystals and sooty walls provide a scheme of thought within which to attend to the sludge which lined the walls of the aircraft wheel bay. It too is suggestive of geological strata, only anthropogenic in origin and with a radically altered time signature. It lends itself too to the reciprocal figuring of part and whole: discrete and connected objects; local and global scales; human and geological time. To empirically ground these thoughts, I teamed up with geologist Andreas Hahn to conduct a microstratigraphic survey of its surfaces.
Samples of transported matter were gathered by applying cut lengths of Sellotape to the wheel bay lining, peeling these off to lift surface deposits, and sealing the lengths in Tupperware boxes. Dr Hahn delivers extracts from his findings in section VII of this paper. In the meantime, I turn to the project of representing the wheel bay in built form.

\section{VI}

On the basis of the measurements taken at the airport, the wheel bay cavity was modelled. From beginnings in graph paper sketches made by Richard on the windswept tarmac (Figure 7), it moved through AutoCAD digital drawings, digital animation, maquette, until emerging as a plywood construction (Figure 8). This was suspended from the ceiling of the gallery of a community arts venue, Watermans Arts, which also lies under the Heathrow flight path and immediately across the Thames from the Botanical Gardens at Kew. ${ }^{3}$

The model sought to occupy a middle ground between monument, architecture, and sculpture. To this end, it was scaled to 0.7, large enough to invoke the original - its contours, proportions, and overwhelming size -, but not to replicate it. The design took the form of a lattice that conformed to an abstract, geometric logic constructed around the cavity, overlaying the void so as to make symbolic use of its otherwise invisible objecthood. Also integral to the design was the ambition to allow the visitor a bodily negotiation of the cavity but to insist on its continuity with the physical environment in which it was housed. In other words, the experience of total immersion was denied. This continuity ensured reciprocal communication between inside and outside, so that audience conversations and visual encounters would be superimposed. This requirement was symbolic as much as practical, indicative of an expectation that the model would exceed its role as spatial representation and fulfil also the function of hypothesis, in this case that it might

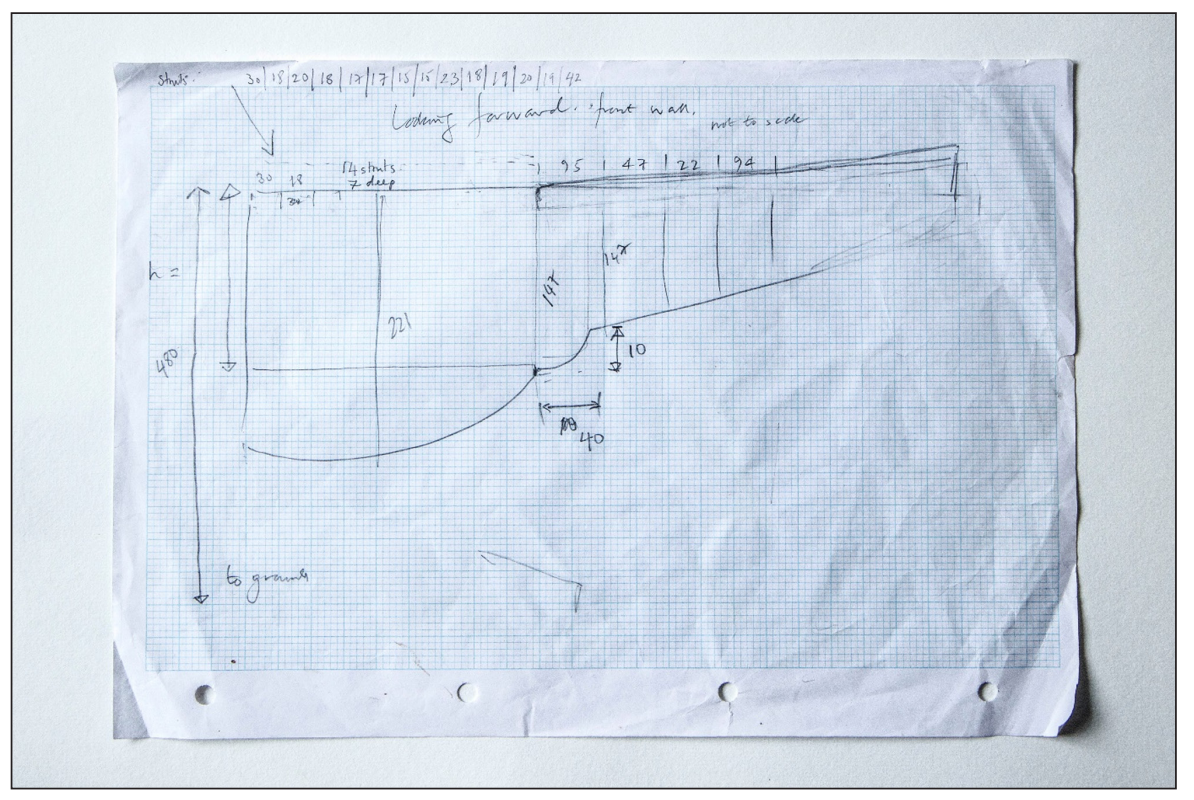

Figure 7: On site drawing of the 777 wheel bay. Drawing: Richard Beard. 


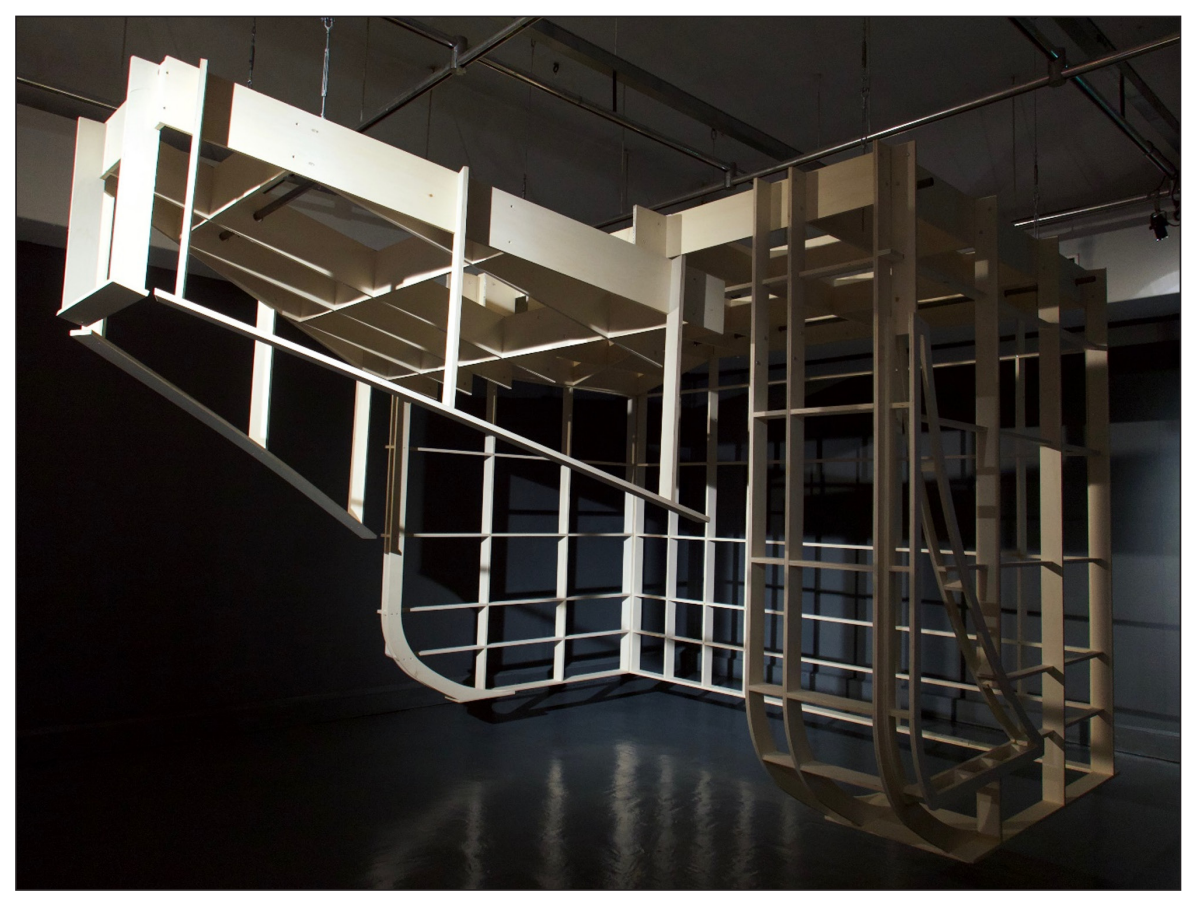

Figure 8: Plywood reconstruction of the wheel bay. Installation view at Watermans Arts, October 2019. Photograph: Phil Harris.

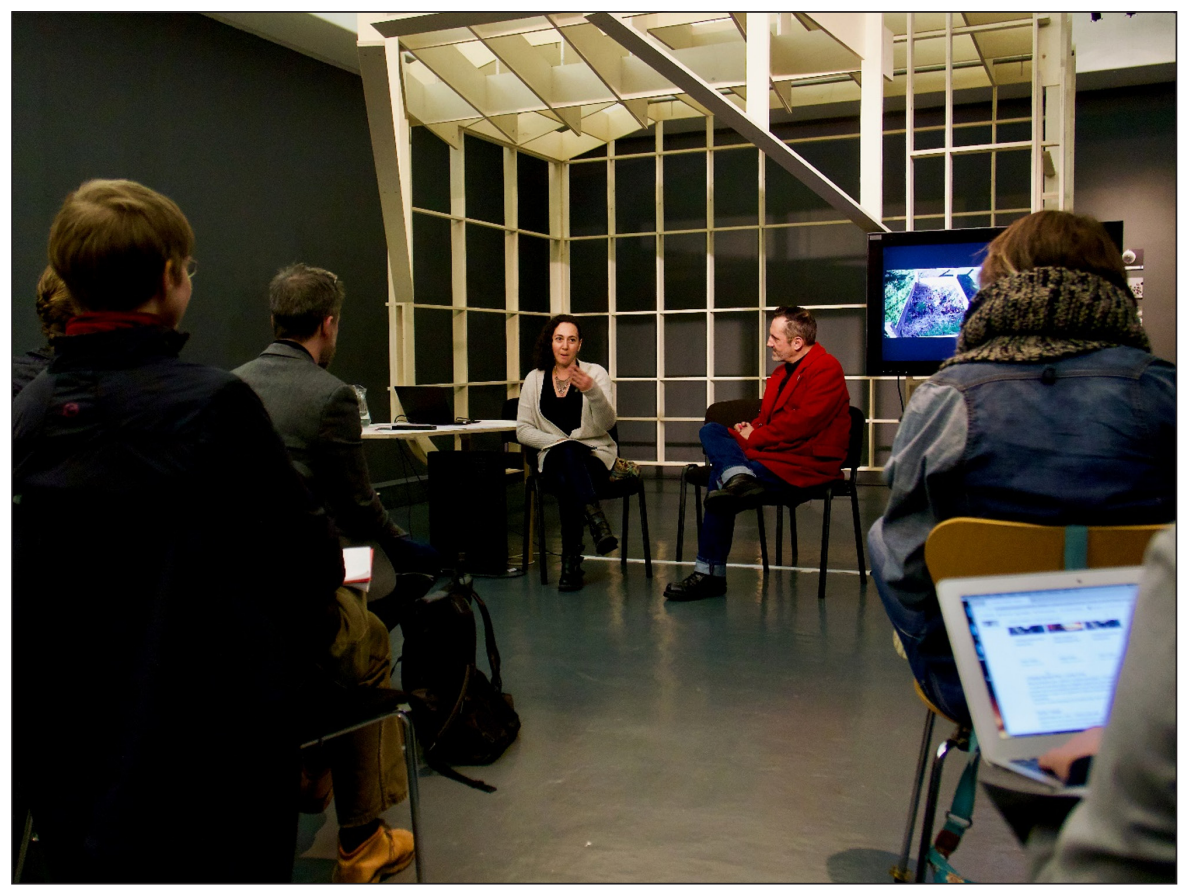

Figure 9: Installation view of Capsule during the symposium Politics of Air, Watermans Arts, November 9, 2019. Photograph: Phil Harris.

serve as a medium through which to capture, bring together and amplify types of information relating to the exhibition theme, but not otherwise experienced as connected.

In line with these formal and social functions, for one day only, the structure was used as a pavilion (Figure 9) in which to host speakers for a symposium, The Politics of Air (Watermans Arts, 2019) The event comprised presentations, discussions, and debates on cultures of air use and its governance. It included contributions from the
Extinction Rebellion splinter group Pause Heathrow who earlier in the year had staged drone attacks on Heathrow Airport, air transport policy studies theorist Steven Griggs, architect Nerea Calvillo and systems theorist Georgina Voss. By bringing the exhibition medium into contact with subject specialists and civil society variously affected by the airport, and by embracing the potential of a layered, discursive, and pedagogic approach, the process sought to reflect the complexity of representing the systemically unaccounted. 


\section{VII}

The findings of the geoforensics study can be differentiated into three categories: (1) Organic biological substances, (2) inorganic mineralogical substances and (3) anthropogenic industrial substances. ${ }^{4}$

A simple assemblage of tree and flower pollen represents the recovered organic matter which is confined to the 'fine' size fraction (20-63 $\mu \mathrm{m}$; (Figure 10). The observed pollen grain characteristics are summarised in Table $\mathbf{1}$. Bisaccate pine tree pollen (family Pinaceae, genus Pinus) consist of a central pollen body (corpus) and two laterallyplaced, chambered sacs (sacci) (Figure 11). Total lengths vary between $60 \mu \mathrm{m}$ and $100 \mu \mathrm{m}$. A discrimination down to species level is difficult due to the morphological resemblance between the numerous native and invasive species in Europe. The Scots Pine (Pinus sylvestris) is the only native conifer in the UK and a potential candidate for the observed pine tree pollen grains.

Spheroidal Asteraceae pollen (composite or sunflower family) with diameters between $15 \mu \mathrm{m}$ and $20 \mu \mathrm{m}$ represent the second, subordinate type of biological matter in the collected samples (Figure 12). The modal proportion between Pinaceae and Asteraceae is approximately 10:1. A species identification is not possible with the collected data due to the large number of eligible candidates. The Asteraceae family includes herbaceous plants (herbs, flowers, weeds) and some woody plants (shrubs, vines, trees) such as the sunflower, lettuce, chamomile, tarragon, chrysanthemum, dandelion and thistle. Asteraceae are endemic to the Northern and Southern Hemisphere, populate all climate zones, have a high biodiversity in Europe and many species are introduced by human activity.

The limitations of the applied sampling and separation methods (small surface area, low sample depth, material $<20 \mu \mathrm{m}$ not analysed) make it difficult to affiliate the identified pollen material with a specific geographic location or to reconstruct dispersion and migration paths. Airborne pollen can be transported over long distances upon release (e.g. Smith et al. 2005; Makra and Pálfi 2007; Skjøth et al. 2007; Rousseau et al. 2008; Izquierdo et al. 2011). Their deposition on a locationindependent vehicle is controlled by multiple factors such as local or regional flora, wind patterns, localised (artificial) air turbulences, residence time, exposure etc. The absence of taxa which are endemic to habitats around

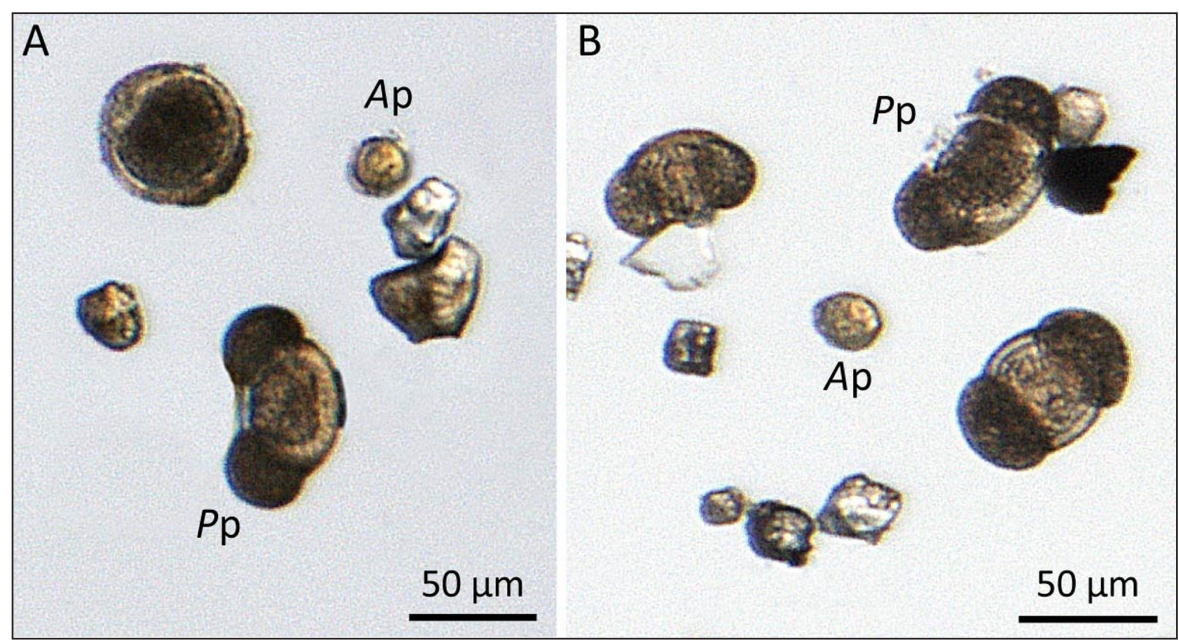

Figure 10: Tree and flower pollen in the 'fine' size fraction $(20-63 \mu \mathrm{m})$. A and B. Transmitted light photomicrographs (plane polarised light) showing Pinus (Pp) and Asteraceae (Ap) pollen together with fragments of bright-coloured transparent (felsic) minerals. Image capture: Andreas Hahn.

Table 1: Summary of the observed pollen characteristics.

\begin{tabular}{lll} 
& Pinus (genus) & Asteraceae (family) \\
\hline Unit & Monad $^{\mathrm{a}}$ & Monad $^{\mathrm{a}}$ \\
Class & Saccate & Colporate \\
Polarity & Heteropolar & Isopolar \\
Shape & Bisaccate & Spheroidal \\
Size (pollen unit) & Large $(50-100 \mu \mathrm{m})$ & Small to medium $(10-50 \mu \mathrm{m})^{\mathrm{b}}$ \\
Aperture type & Leptoma $^{\mathrm{d}}$ & Colporate $^{\mathrm{e}}$ \\
Ornamentation & Verrucate $^{\mathrm{f}}($ cappa $)$ & Echinate $^{\mathrm{g}}$
\end{tabular}

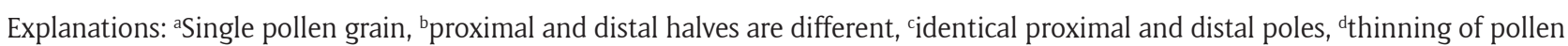
wall at distal pole, presumably the germination area, ${ }^{e}$ elongated colpus (ektoaperture) combined with porus (endoaperture), ${ }^{f}$ wartlike elements on pollen wall larger than $1 \mu \mathrm{m}$, broader than higher (pl. verrucae, sspine-like ornamentation element on pollen wall longer or wider than $1 \mu \mathrm{m}$ (pl. echini). 


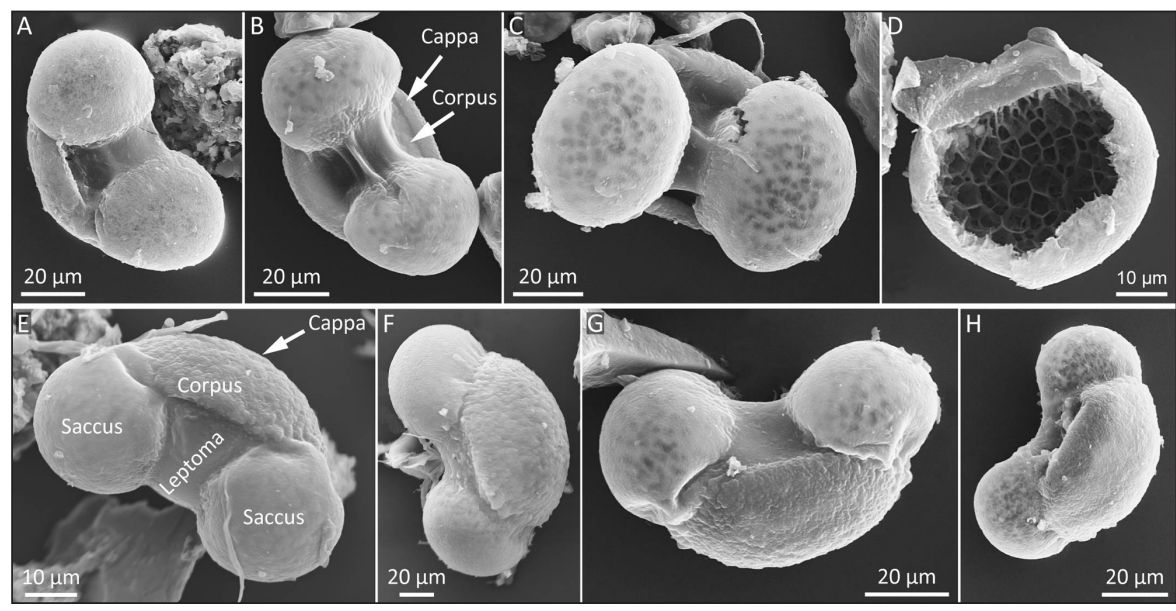

Figure 11: Scanning electron microscope micrographs (secondary electron images) of Pinus pollen grains in the 'fine' fraction $(20-63 \mu \mathrm{m})$ of the separated sample material. A-C) Polar distal view. D) Inside of a detached saccus. Note the hexagonal-shaped air chambers. E-H) Straight to oblique equatorial view on fresh hydrated pollen grains illustrating characteristic morphological features. Image capture: Andreas Hahn.

the Persian Gulf (e.g. halophytes or xerophytes) points to a pollen provenance in the vicinity of the last layover and/or compound site, despite the described sampling biases.

Light and dark coloured minerals comprise the inorganic particles of natural origin in both separated size fractions (Figure 13). The mineral matter is preserved as complete or fragmented crystals with vitreous lustre and angular to rounded shapes of low to medium sphericity. Mineral surfaces are smooth or scratched, cracked, pitted, porous or frosted as a result of physical and/or chemical abrasion. Grain sizes range from medium-coarse silt (15.6 $\mu \mathrm{m}$ to $63 \mu \mathrm{m}$ ) to very fine and medium sand ( $>63 \mu \mathrm{m}$ to $500 \mu \mathrm{m}$ ) with a predominance of coarse silt to very fine sand particles between $30 \mu \mathrm{m}$ and $100 \mu \mathrm{m} .{ }^{5}$

Crystallographic-mineralogical and optical characteristics identify the inorganic particles as predominantly felsic (light coloured) silicate minerals with minor mafic (dark coloured) silicates plus iron oxides and iron oxide-hydroxides. The latter are common weathering and alteration products of primary iron-bearing minerals

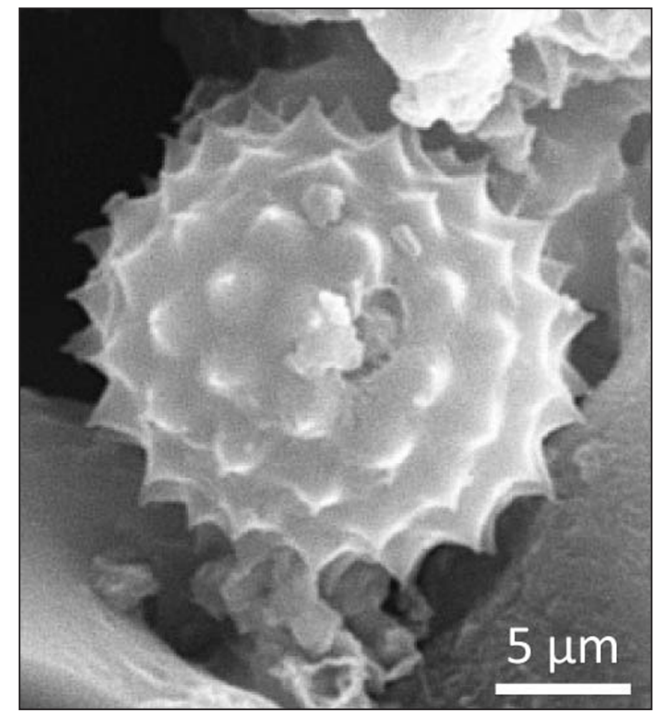

Figure 12: Secondary electron image (SEM) of a mediumsized colporate Asteraceae pollen grain with echinate ornamentation and elongated colpus (ektoaperture). Image capture: Andreas Hahn.

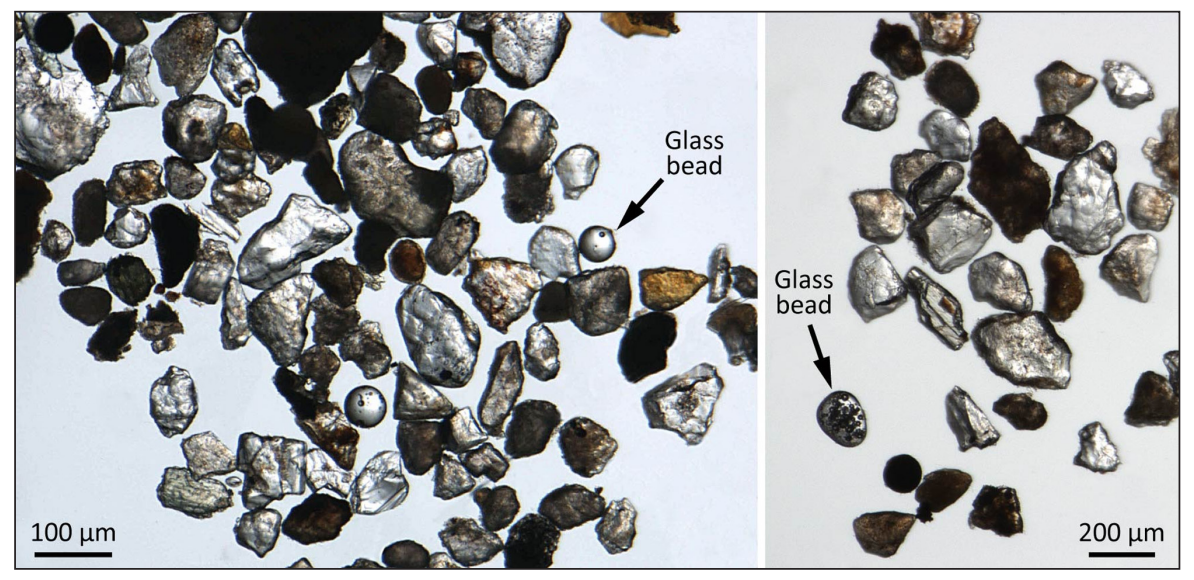

Figure 13: Transmitted light photomicrographs (plane polarised light) showing predominantly angular to sub-angular, felsic (bright) and mafic (dark) mineral fragments in the 63-255 $\mu \mathrm{m}$-fraction, together with spherical to oval shaped glass beads. Image capture: Andreas Hahn. 
or of men-made steel products (rust). Quartz $\left(\mathrm{SiO}_{2}\right)$ is the dominant felsic mineral in both size fractions. Felsic silicate minerals (from feldspar and silica) are relative enriched in elements with lower mass numbers (e.g. silicon, aluminium, potassium) and have usually specific densities under $3.0 \mathrm{~g} / \mathrm{cm}^{3}$. The darker mafic (from magnesium and ferric iron) silicates contain more elements with higher mass numbers such as magnesium, iron, calcium, and sodium and yield specific densities above $3.0 \mathrm{~g} / \mathrm{cm}^{3}$.

Quartz and feldspar minerals are common (felsic) rockforming minerals in the continental crust (e.g. in granite or andesite). Abundance makes them accessible for natural mobilisation, transportation and (re-) deposition. The lift force on particles is depended on the flow velocity but also particle features such as size, density, shape, and mechanical robustness (hardness). Strong land winds have top speeds around $30 \mathrm{~m} / \mathrm{s}$ (8 Beaufort) which limits the maximum size of wind-driven aeolian material to medium sand $(250-500 \mu \mathrm{m})$, creating a natural sorting effect (Pye, 1987; Nickling, 1994). Increased particle roundness, frosted or pitted grain surfaces and compositional maturation (dominance of mechanical, robust minerals such as quartz) are characteristic for aeolian sediments and indicative of prolonged airborne transport. Anthropogenic processes such as traffic-related air turbulences interfere locally with wind-driven aeolian processes on and close to surface level in areas with infrastructure. This has an effect on the nature and composition of airborne particles in proximity to transportation hubs.

An additional (complicating) factor is the omnipresence of mineral construction material and waste in agglomerations. This makes is difficult to identify the sediment particle provenance in this study with absolute certainty. Nature and composition of the recovered mineral material speak against an 'exotic' origin of the observed mineral particles. The maximum particle size conforms with existing models for wind-driven (aeolian) sediment transport and deposition. Mineralogical composition and particle texture, however, speak against a prolonged airborne transport typical for dune sands on the Arabian Peninsula. Another indicator is the absence of evaporite minerals (carbonates, sulphates and halides such as calcite, anhydrite, gypsum and halite) which are common in supra-tidal mud- and sand flats in semi-arid to arid areas, called sabkhas. A type location for sabkhas are the coastal lowlands of the southern Persian Gulf in the United Arab Emirates, the former operational hub of 777-200LR A6-LRC. A possible origin for the recovered mineral material are areas in and around the last layover and/or compound sites.

Spheroidal to oval, colourless-transparent glass beads with diameters between $35 \mu \mathrm{m}$ and $100 \mu \mathrm{m}$ are the only inorganic sample material which is unequivocally anthropogenic in nature (Figure 14). Unspecified iron oxides and iron oxide-hydroxides are either fragments of altered mafic minerals or of men-made steel products. The measured bead diameters $(n=38)$ cluster around $35 \mu \mathrm{m}$, $50 \mu \mathrm{m}, 60 \mu \mathrm{m}, 75 \mu \mathrm{m}$ and $100 \mu \mathrm{m}$ which is indicative of standardised size fractions. All glass beads have smooth surfaces and are not coated. Most of the observed glass spheres (ca. 70\%) are solid, some are hollow with circular holes (10-25 $\mu \mathrm{m}$ in diameter depending of bead size) and/or contain gas (air) bubbles.

Glass beads have many technical application across a wide range of industries such as oil and gas, chemicals, construction materials, aerospace, building products, construction and engineering, electrical equipment, machinery, airlines, marine, road and rail, transportation
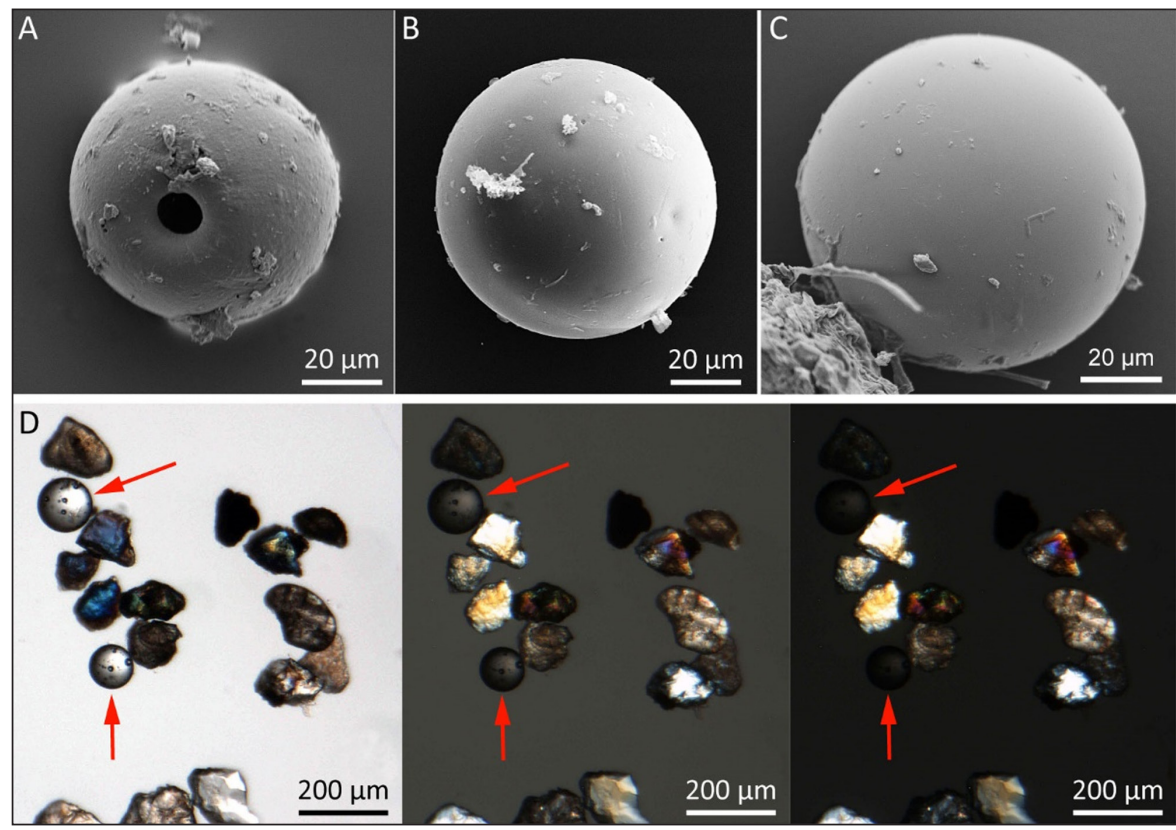

Figure 14: Industrial glass beads in the recovered sample material. A and B) Secondary (SEM-SE) images of hollow (A) and solid (B) spherical glass beads in the 'coarse' size fraction. C) Glass microspheres for road marking and traffic paint (Anhui Tory Material Technology Inc. 2020). D) Transmitted light photomicrographs of glass beads (red arrows), felsic and mafic minerals in cross polarised light in three different polariser-analyser alignments. Mineral matter (with a crystal lattice) reveals varying birefringence colours while amorphous glass remains dark. 
infrastructure, auto components, automobiles, household durables, electronic equipment, instruments and components, electric and water utilities (following the Global Industry Classification Standard; S\&P Global 2020). Commercial bead sizes range from less than 40 $\mu \mathrm{m}$ up to several millimetres are made of soda-lime glass (70-75 wt.\% $\mathrm{SiO}_{2}, 12-16$ wt.\% $\mathrm{Na}_{2} \mathrm{O}, 10-15$ wt.\% $\mathrm{CaO}$ ) or borosilicate glass (70-80 wt.\% $\mathrm{SiO}_{2}, 7-13 \mathrm{wt} . \% \mathrm{~B}_{2} \mathrm{O}_{3}$, 4-8 wt.\% $\mathrm{Na}_{2} \mathrm{O}+\mathrm{K}_{2} \mathrm{O}, 2-8$ wt.\% $\mathrm{Al}_{2} \mathrm{O}_{3}$; Bauccio, 1994; Pfaender, 1996). The application in reflective paints for traffic markings (such as airfield runways) as well as surface treatments (e.g. peening and blasting) in the aerospace industry is the most plausible explanation for glass beads in the sample material. The observed glass bead properties characterise a variegated assemblage of different bead types with differing purposes. The production source of the glass beads remain enigmatic due to their global distribution.

Industrial glass beads are considered an ecologically friendly material which is to some extent reusable through recycling schemes. However, a large proportion of the material enters the natural environment as poorly or non-decomposable solid waste. The physico-chemical and thermal properties make glass inert and stable towards natural decay processes and preserves it in natural systems as anthropogenic matter over thousand to millions of years. The smallest commercially sold glass bead fractions represent respirable health-damaging particles according to the currently valid WHO Air quality guidelines. The World Health Organisation (2020) defines atmospheric particulate matter (PM) as solid and liquid substances of organic and inorganic origin which are suspended in the air. The health hazard depends on penetration depth and therewith on particle size. Coarse particulate matter $\left(\mathrm{PM}_{10}\right)$ with aerodynamic particle diameters $\leq 10 \mu \mathrm{m}$ can invade deeper parts of the respiratory system while fine particulate matter $\left(\mathrm{PM}_{2.5} \leq 2.5 \mu \mathrm{m}\right)$ may even cross the barrier into the circulatory system.

\section{VIII}

That a glass bead a mere 35 micrometers in diameter can be seen in all its detail while a human body goes undetected is a damning indictment of knowledge cultures. It invites urgent and serious reflection on the limitations of our methodologies, and an urgent call for their reconfiguration.

The discovery of the glass beads brings to attention a further constituent of the material fusion that takes place in the wheel bay, as well as a further material entity dispersed into the air through aircraft movement. This much we know: the microscopic beads are dislodged from the emulsion that fixes them to the runway by the force accelerating or breaking aircraft tyres and, once loose, are drawn into the wheel bay in the manner of the other matter. Here they integrate with and are dispersed in the same manner as the other organic and inorganic particles. As they descend through the air around airports, these particles are readily integrated into the respiratory and digestive systems of living organisms, contributing to an invisible and unauthorised form of biopolitics, whereby life forms find themselves altered by the activities of the state or the industry that it sanctions. Thus, their discovery in the wheel bay adds force to a moving body of evidence of the fouling of a shared and finite planetary resource by private enterprise. It is not known what wider influence the beads are having on life, though findings relating to other industrially generated particulates suggest that, as Ruskin speculated, if we knew where and on what scale to look, it is likely to be significant.

We get a glimpse of what to expect from the modelling moving objects by architect Adrian Lahoud. Lahoud's study is doubly relevant to the present context because his modelling practice takes by way of case study the movement of particulates in relation to that of migrants. Lahoud states that the difficulty of discerning the effect of a moving object is a problem of modelling (2016). Explanations used to understand the behaviour of a migrant come from the humanities, while those used to understand the environment rely on science. What happens, he asks, when these different epistemologies are brought into contact? What happens when environmental models intercept models of human character? Through these speculations, the scales of particles and lived histories are brought into contact. Aerosols, a by-product of fossil fuels, move around the globe but have a signature - 'like a fingerprint on a crime scene' that enables their origins to be traced (Lahoud 2016: 114). Their effect is difficult to model and quantify precisely, but we know they are produced in the oil refining processes carried out mainly in Europe and North America and change sea temperature and affect rainfall on the African continent. To this extent, we can speak of their impact as travelling south. From research in cultural geography, meanwhile, we know that rural communities in sub-Saharan Africa are on the move to the cities, or north towards Europe because of environmental changes that are not of their own making. While no straightforward mechanism of cause and effect has been demonstrated, the bringing together of two modelling systems enables Lahoud to observe that 'The southward trajectory of aerosols and their effects on the climate of the Sahel and the northward trajectory of migrants attempting to flee sub-Saharan Africa and enter Europe aligns in a pernicious geometry. What gets emitted as a particle returns as a refugee...' (ibid. 115).

\section{IX}

The migrant's body fell with a 'whomp'. The onomatopoeia, commensurate with the English language representation of a speeding mass splitting the air and colliding with the ground, was reported by an anonymous earwitness who had been prompted to look from an upstairs window. It was quickly jumped upon by the press and was reproduced alongside an image of an aircraft. As I scrolled through its various iterations, I wondered whether I was expected to gasp or laugh. 'Whomp' embodies at once the gravitas of a testimonial and the release afforded by an encounter with the absurd. The uncertainty, I concluded, was calculated, positioning the reader at the nexus of indignation and amusement. Each newspaper set it up slightly differently but maintained the balance.

When Baldock was woken from his sun lounger on that July afternoon, he was said to be visibly shaken. 
Understandably. There was a corpse in his garden. That it had fallen from the sky was immediately apparent. Though frozen almost solid, the body had hit the ground with such force that blood splattered the fence and walls of the premises. But Baldock, a scientifically minded man with an engineering degree would have known as well as anyone that people do not just fall out of the sky. His visitor's arrival bears the hallmarks of a tasteless joke played by an accomplished prankster, a stunt whose seeming ability to defy physics is as inexplicable as its purpose. Though they exist in proximity - in the case in point a mere 3,500ft - the worlds of air travel and dwelling are psychically closeted from each other. In the metropolitan imaginary Clapham does not extend upwards as far as the firmament and the passengers of overhead planes are sealed in a pressurised cabin. Who in the immediacy of the moment would have reached for the explanation later provided by the Metropolitan Police?

In physical terms, it is as if two discrete space-times have collided, the first the here and now - the time of the foreseen and observed - the second the future, an unruly and uncertain unfolding of the not-yet-imagined that, having bypassed the normal duration that affords the transition of one thing into another has arrived without due process. The effect is a sense of a traveller bursting into history, as if theologically, a deus ex machina enlisted to resolve a seemingly hopeless situation in the plot of a classical drama. And, as happens with jokes, even as they prompt laughter, the sudden and absurd juxtaposition of two worlds works upon thought, so the migrant's descent into the leafy London suburb attunes the mind, sparking a new register of consciousness until the framework of possible presents is expanded to accommodate them.

The migrant came to rest three feet from Baldock at 15.40 BST. One human body next to another. Kenya is two hours ahead of the United Kingdom, making it 13.40 by the body clock of the newly arrived. This small difference in time conceals, however, a vast separation in the space the world order has allocated to each body. We learn more about the gap from the Indian postcolonial sociologist Dipesh Chakrabarti. Chakrabarti has sought to show that the earth of globalisation is not the same earth as the one imagined in environmental politics. The former is human centred and constructed in relation to human needs, specifically the economic globalisation agendas of societies in the Global North. The latter belongs to earth system science and is constructed in relation to the solar system, as well as the needs of planetary life (Chakrabarty 2018). The effect of planetary changes such as global warming is felt most acutely among people from the developing world and in political terms it is to the planetary that people from the developing world are assigned. If Lahoud helps us mentally encompass vectors through which the two bodies came together at Clapham, Chakrabarti makes clear that the three feet separating them represents the distance between a protagonist from one globe and a protagonist from the other. In this alone it is a remarkable image, for the distance has been violently compressed.

Whether a person can be seen and heard, or is invisible and without avoice, depends on which globe they have been assigned. It is a spatial arrangement philosopher Jacques
Rancière has labelled the distribution of the sensible and the primary aesthetics of politics (Rancière 2006). The term sensible designates an openness to experience, rather than the contemporary English meaning - showing good judgement. If the body of a ticketed plane passenger passing over the neighbourhood fails to be registered by the body politic of Clapham, how much more invisible is the body who has clung to an aircraft undercarriage. The migrant sought to redress his invisibility by overcoming spatial differentiation. We might think of his approach as a kind of shortcut through the spacetime of development. Insofar as the aircraft wheel bay was his vehicle of choice, it must be counted as a site of political struggle.

How long it took Baldock to realise that his guest had fallen from an aircraft, the story does not narrate. We do know that by way of convalescence, he returned to the home of his parents outside the capital. Though a Sunday afternoon, it was not a simple matter of getting back on the lounger once the puzzle of how the man had come to fall into his garden had been solved. For the violence of finding oneself adjacent on a sun lounger to a man who has from the sky has not so much to do with the absence of a proximate cause, but with its uncanny ability to bring into focus distant causes.

\section{$\mathrm{X}$}

In natural history terms, the flow of planes in and out of Heathrow are contributing to the formation of new landscapes and new species-intermingling in the vicinity of airports. The analogies of the glacier and river may be useful in comprehending this evolution because one aspect of what is being steadily produced is a new sedimentary layer that starts at about five kilometres from the airport - the point at which the landing gear is opened - and becomes increasingly more concentrated towards the runway. In his book Thames, Sacred River, Peter Ackroyd notes 'The river contains its beginning within its end' (2008:17). The same may be said of the flight path.

Another analogy might be the planetary garden. According to this concept, the planet can be thought of as one vast garden, a privileged site in which species are brought into contact with each other through human activity (Clément n.d.). New habitats, colonies and biomes are developing. Thus, aircraft movement has scattered the Western corn rootworm indigenous to North America, Diabrotica virgifera virgifera, in the vicinity of European airports. The planetary garden concept brings detail to the globe of system science mentioned earlier. It shows that the garden is finite, life precious and precarious. It commits the gardener to planetary flourishing - human wellbeing depends on it - and to acting with due care and responsibility. It offers a way of thinking the cohabitation of different sections of the world accidentally thrown together, and of the need for humans to negotiate with each discrete environment rather than impose an order on it. Through these conditions, however, it also holds to account the aircraft-gardener. For as we have seen, the landing gear compartment is no such horticulturalist. Species incapable of cohabitation are carelessly thrown together and the gardener's dinner is at risk. In a 
portentous report that weighs heavily on the colonial imagination, we hear from the British Government at Windsor Castle, just a few kilometres west of Heathrow, the Western corn rootworm has been found: 'eating the Queen's corn crops' (UK Gov. 2006).

\section{XI}

As I tell this story, humanity is in the grips of a global pandemic. A new strain of virus, SARS-CoV-2 (Covid 19), capable of infecting humans has been transported from its breeding ground in Wuhan, China, to all corners of the globe. The virus travels by air. Droplet born, it rides on airborne bodily fluid until entering a new host, necessitating changes in the spatial relationships between bodies unprecedented in human memory, and radically transforming public life. And as each infected body is transported by plane from one country to the next, it is spread around the globe. Covid 19 and its aesthetic manifestations are arguably an aviation landscape par excellence.

These are significant developments in the entanglement of aviation, mobility justice and planetary justice. An exposition of their relationship will need to wait, but we get a sense of what is at large when we learn that Covid 19 is disproportionately affecting people of colour. The discovery brings to wider public attention embedded prejudices in European and US postcolonial societal structures, and invites searching questions about how these work at the level of atmospheric science. In a set of preliminary findings Martelletti and Martelletti (2020) suggest that the fluid has a habit of sticking to PM10 particulates, more commonly known as air pollution, and this may enable it to travel further. They write: 'Atmospheric PM has a sub-layer that facilitates the virus survival in airflows for hours or days.' Where pollution is higher, so are infection rates. When read in the knowledge that high levels of pollution are found in the kinds of neighbourhood where economic migrants tend to settle - airport and factory suburbs in demand of labour forces - their findings point to a toxic politics of aviation and the right to the city.

In relation to planetary justice, it seems fitting that the ideas set down in this paper are being developed in the context of a global lockdown. The virus has forced upon the landscape what Kew's aphid infestation only forecast. Until contained, a new spatial order reigns. Air travel, other than for the purposes of freight and the repatriation of citizens, has all but halted. At Heathrow empty shuttle busses trundled prosaically around the compound and verges grow unchecked. A long-stay carpark has been turned into a drive-through virus test centre.

What of the glass beads discovered in the wheel bay? By virtue of their size, their impact on the landscape is harder to detect. But for sure, as the freshly crafted ornaments are spilled carelessly around the grounds of the estate, they will be leaving a fluorescent trace. At present, this is visible only if the soil is inspected under a microscope. With time, though, it promises to become stronger and brighter. Perhaps it will be thought of as land art, something in the order of the Neolithic henges and stone circles. Perhaps one night it will even come to guide observers of the Anthropocene to the sites where Heathrow's runways once lay.

\section{Notes}

${ }^{1}$ The failure to account for the migrant would seem to be systemic. Despite efforts made by the Metropolitan Police, their Kenyan counterparts and the airline, the identity of the migrant was not discovered. An e-fit photograph was published by the Metropolitan Police on October 2, 2019, but no conclusive identification of the victim has been reached.

2 The phrase 'hitchhiking pests' was used by Sarah Redstone, Senior Plant Health \& Quarantine Officer, The Royal Botanical Gardens, Kew, in email correspondence with one of the authors, June 5, 2019.

${ }^{3}$ The work, Capsule, was incorporated into the visual arts group exhibition, Air Matters. Learning from Heathrow, that ran from October 2019 to January 2020. It was curated by the author in collaboration with Klio Krajewska, Watermans Arts.

${ }^{4}$ A fuller version of this report, including details of the methodology, is available online at: http:// nickferguson.co.uk/pdfs/Geoforensics\%20report\%20 \%28website\%29.pdf.

${ }^{5}$ According to the Udden-Wentworth grain-size scale for siliciclastic sediments (Wentworth, 1922). The technical term sand does not refer to the composition of a sediment but to the dominate particle size.

\section{Acknowledgements}

The authors would also like to thank artist Richard Beard, designer Tommy Haycocks, and curator Klio Krajewska for their contributions to the project. Thanks also go to Sarah Redstone, the Royal Botanical Gardens, Kew, for time taken in correspondence, and Mark Gregory of Air Salvage International for access to the aircraft used in the study.

\section{Funding Information}

The research for this paper was made possible with the generous support of Arts Council England, Kingston School of Art, Richmond University, and Watermans Arts.

\section{Competing Interests}

The authors have no competing interests to declare.

\section{Author Information}

Nick Ferguson is an artist based in London. He is Associate Dean for Research at Richmond the American University in London and Senior Lecturer in Critical and Historical Studies at Kingston School of Art. His research examines the relationship between art, space, and power, with recent and ongoing projects focusing on London Heathrow, its neighbourhoods and airspace. His work has featured at/in the Economist Plaza, Journal of Cultural Geography, Marya Art Centre UAE, Places Journal, Tate Modern, Tate Liverpool, Wyspa Gallery, Poland.

Andreas Hahn is a London-based Exploration Geologist and Applied Geoscientist. Until July 2020 he worked as lecturer in geology at the Department for Geography, Geology and the Environment, Kingston University London. His work as researcher and industry consultant 
focuses on subjects related to igneous and metamorphic geology, geochemistry, applied earth and analytical sciences, mineral exploration and deposit studies as well as applied geoforensics.

\section{References}

Ackroyd, P. (2008). Thames Sacred River. Vintage Books.

Back, L. (2003). Falling from the Sky. Patterns of Prejudice, 37(3), 341-353. DOI: https://doi. org/10.1080/00313220307595

Busby, M. (2019). Body of plane stowaway found in London garden. The Guardian. July 1, 2019. Available at: https://www.theguardian.com/uk-news/2019/ jul/01/body-of-suspected-plane-stowaway-found-insouth-london-garden. Retrieved July 1, 2019.

Centre for Invasive Species and Ecosystem Health. (n.d.) Available at: https://www.invasive.org/browse/ subinfo.cfm?sub=21012. Retrieved June 25, 2019.

Chakrabarty. D. (2018). Planetary Crises and the Difficulty of Being Modern Millennium: Journal of International Studies, 46(3), 259-282. DOI: https:// doi.org/10.1177/0305829818771277

Civil Aviation Authority. (2015). Corporate communications external information service. Available at: https://www.caa.co.uk/uploadedFiles/ CAA/Content/Standard_Content/Our_work/ Information_requests/Disclosure_log/2015/ F0002280Reply.pdf. Retrieved: August 10, 2019.

Clément, G. (n.d.) Le Jardin Planétaire. In: A. Jaque, et al. (Eds.), 2018. Manifesta 12 Palermo. The Planetary Garden. Cultivating Coexistence Reader (pp. 46-47). Amsterdam: Manifesta Foundation.

Daston, L., \& Galison, P. (2010). Objectivity. New York: Zone Books

Duell, M, Fielding, C., \& Dyer, C. (2019). First picture of Oxford graduate sunbather who had miracle escape when frozen stowaway plunged 3,500ft from Kenya Airways jet and landed just THREE FEET from him in London garden. The Daily Mail. July 2, 2019. Available at: https://www.dailymail.co.uk/ news/article-7201733/Body-London-garden-fellHeathrow-bound-plane.html. Retrieved July 10, 2020.

Fanon, F. (2001). [1961]. The Wretched of the Earth. London: Penguin. DOI: https://doi.org/10.1007/9781-137-05194-3_4

Farley, P., \& Simmonds Roberts, M. (2011). Edgelands: Journeys into England's True Wilderness. London: Jonathan Cape.

Ginzburg, C., \& Davin, A. (1980). Morelli, Freud and Sherlock Holmes: Clues and Scientific Method. History Workshop, 9(Spring, 1980), 5-36. DOI: https://doi. org/10.1093/hwj/9.1.5

HACAN. (2005). Kew Gardens Stays Silent on Heathrow Expansion at a time key BAA and BA Figures Play a Leading Role in its Management. Press Release 16.08.05. Available at: https://hacan.org.uk/?p=5965. Retrieved July 11, 2020.

Haughian, S. R., et al. (2016). A Checklist of the Marchantiophyta and Anthocerotophyta of New
Brunswick, Canada. Northeastern Naturalist, 23(13), 1-35. DOI: https://doi.org/10.1656/045.023.m1 301

Hawksworth, D., \& Lücking, R. (2017). Fungal Diversity Revisited: 2.2 to 3.8 Million Species. Microbiology Spectrum, 5(4). DOI: https://doi.org/10.1128/ microbiolspec.FUNK-0052-2016

Izquierdo, R., Belmonte, J., Avila, A., Alarćon, M., Cuevas, E., \& Alonso-Pérez, S. (2011). Source Areas and Long-Range Transport of Pollen from Continental Land to Tenerife (Canary Islands). International Journal of Biometeorology, 66(1), 67-85. DOI: https://doi. org/10.1007/s00484-010-0309-1

Lahoud, A. (2016). Scale as Problem. Architecture as Trap. The Avery Review. Issue 15. Available at: http://www. averyreview.com/issues/15/architecture-as-trap

Landy, M. (2002). Nourishment. London: Paragon Press.

Latour, B. (2006). From Realpolitik to Dingpolitik or How to Make Things Public. In: B. Latour \& P. Weibel (Eds.), Making Things Public. Catalogue for an Exhibition. Cambridge, MA: ZKM Centre for Art and Media Karlsruhe and The MIT Press.

Martelletti, L., \& Martelletti, P. (2020). Air Pollution and the Novel Covid-19 Disease: a Putative Disease Risk Factor. SN Comprehensive Clinical Medicine (pp. 1-5). Advance online publication. Retrieved May 22, 2020. DOI: https://doi.org/10.1007/s42399-02000274-4

Morton, T. (2017). The Golden Stain of Time. Lecture at SCI-Arc, Los Angeles, March 7. Available at: https:// www.youtube.com/watch?v=QQjaTOxGDw4. Retrieved July 7, 2019.

Nickling, W. G. (1994). Aeolian Sediment Transport and Deposition. In: K. Pye (Ed.), Sediment Transport and Depositional Processes. Oxford: Blackwell Scientific Publications.

Pye, K. (1987). Aeolian Dust and Dust Deposits. London, Academic Press.

Rancière, J. (2006). The Politics of Aesthetics. Trans. Gabriel Rockhill. London: Continuum.

Rousseau, D.-D., Schevin, P., Ferrier, J., Jolly, D., Andreasen, T., Ascanius, S. E., Hendriksen, S.-E. \& Poulsen, U. (2008). Long Distance Pollen Transport From North America to Greenland In Spring. Journal of Geophysical Research, 113, G02013. DOI: https:// doi.org/10.1029/2007JG000456

Ruskin, J. (1900). [1865]. The Lamp of Memory. In: The Seven Lamps of Architecture. Boston: Dana Estes $\&$ Co. [online]. Available at: https://ia800204. us.archive.org/18/items/sevenlampsofarch01rusk/ sevenlampsofarch01rusk.pdf

Ruskin, J. (1865). The Ethics of Dust. CreateSpace Independent Publishing Platform.

S\&P Global. (2020). GICS $\AA$ Global Industry Classification Standard. [Online] Available from: https://www.spglobal.com/marketintelligence/en/ documents/112727-gics-mapbook_2018_v3_letter_ digitalspreads.pdf. Accessed May 2020.

Skjøth, C. A., Sommer, J., Stach, A., Smith, M., \& Brandt, J. (2007). The Long-Range Transport of Birch (Betula) 
Pollen From Poland and Germany Causes Significant Pre-Season Concentrations in Denmark. Clinical and Experimental Allergy, 37(8), 1204-1212. DOI: https:// doi.org/10.1111/j.1365-2222.2007.02771.x

Smith, M., Emberlin, J., \& Kress, A. (2005). Examining High Magnitude Grass Pollen Episodes at Worcester, United Kingdom, Using Back-Trajectory Analysis. Aerobiologia, 21(2), 85-94. DOI: https://doi. org/10.1007/s10453-005-4178-8

Smithson, R. 1996. [1967]. A Tour of the Monuments of Passiac, New Jersey. In: J. Flam (Ed.), Robert Smithson: The Collected Writings. Berkeley, CA: University of California Press.

Stroyan, H. (1981). Plant Pathology, 30(4), 253. DOI: https://doi.org/10.1111/j.1365-3059.1981.tb012 66.x

Taylor, D. (2018). Kweku Adoboli deported to Ghana on flight from Heathrow. The Guardian. https://www. theguardian.com/uk-news/2018/nov/14/kwekuadoboli-rogue-trader-ubs-deported-ghana-heathrow. Retrieved Feb 25, 2020.

Thereza Alves, M. (2009). Seeds of Change. Available at: http://www.mariatherezaalves.org/works/seeds-ofchange-marseille?c=47. Retrieved March 23, 2020.
UK Government Department for Food, Environment and Rural Affairs. (2006). Western Corn Rootworm, Diabrotica virgifera virgifera. Available at: https:// planthealthportal.defra.gov.uk/assets/factsheets/ csldiab.pdf. Retrieved Feb 21, 2020.

UK Government Department for Transport. (2018). Airports National Policy Statement. Available at: https://www.gov.uk/government/publications/airports -national-policy-statement. Retrieved Feb 21, 2020.

Wagner, A. (2005). Being There: Art and the Politics of Place. Artforum, 43(10), Summer 2005.

Watermans Arts. (2019). Politics of Air. Available at: https://www.watermans.org.uk/new-media-artsarchive/air-matters-symposium-politics-of-air/. Retrieved: Feb 08, 2020.

Weizman, E. (2017). Forensic Architecture: Violence at the Threshold of Detectability. New York: Zone Books - MIT. DOI: https://doi.org/10.2307/j.ctv14gphth

Wentworth, C. K. (1922). A Scale of Grade and Class Terms for Clastic Sediments. Journal of Geology, 30, 377-392. DOI: https://doi.org/10.1086/622910

Wikipedia. (n.d.). List of Wheel-Well Stowaway Flights. Available at: https://en.wikipedia.org/wiki/List_of_ wheel-well_stowaway_flights. Retrieved May 21, 2020.

\footnotetext{
How to cite this article: Ferguson, N., \& Hahn, A. (2021). Landscapes of Heathrow: The Aircraft Landing Gear Compartment and the Politics of Global Transfer. Anthropocenes - Human, Inhuman, Posthuman, 2(1): 5. DOI: https://doi.org/10.16997/ahip.930

Submitted: 20 June 2020

Accepted: 10 November 2020

Published: 31 May 2021

Copyright: ๑ 2021 The Author(s). This is an open-access article distributed under the terms of the Creative Commons Attribution 4.0 International License (CC-BY 4.0), which permits unrestricted use, distribution, and reproduction in any medium, provided the original author and source are credited. See http://creativecommons.org/licenses/by/4.0/.
} 